\title{
CORTISOL AND SEROTONIN LEVELS IN SCHIZOPHRENIC INPATIENTS UNDERGOING AEROBIC TRAINING
}

\author{
NIVEIS DE CORTISOL E SEROTONINA EM PACIENTES ESQUIZOFRENNICOS SUBMETIDOS A \\ TREINAMENTO AERÓBICO

\begin{abstract}
NIVELES DE CORTISOL Y SEROTONINA EN PACIENTES ESQUIZOFRÉNICOS SOMETIDOS A ENTRENAMIENTO AERÓBICO
\end{abstract}

Original Article

ARTIGO ORIGINAL

Artículo Original

\begin{abstract}
Lígia Gizely dos Santos Chaves ${ }^{1}$ (DD (Physical Education Professional)

Dirceu Ribeiro Nogueira da Gama².(ID) (Physical Education Professional)

Juliana Brandão Pinto de Castro 2,3 (ID) (Physical Education Professional)

Kleber Roberto da Silva Gonçalves de Oliveira' (ID

(Physician)

Rodrigo Gomes de Souza Vale 2,3,4 (iD)
\end{abstract} (Physical Education Professional)

1. Fundação Pública Estadual Hospital de Clínicas Gaspar Vianna, Belém, PA, Brazil.

2. Universidade do Estado do Rio de Janeiro (UERJ), Postgraduate Program in Exercise and Sport Sciences, Rio de Janeiro, RJ, Brazil. 3. Universidade do Estado do Rio de Janeiro (UERJ), Exercise and Sport Laboratory (LABEES), Rio de Janeiro, RJ, Brazil.

4. Universidade Estácio de Sá, Laboratório de Fisiologia do Exercício, Cabo Frio, RJ, Brazil.

\section{Correspondence:}

Juliana Brandão Pinto de Castro. Universidade do Estado do Rio de Janeiro (UERJ).

Rua São Francisco Xavier, 524, Pavilhão João Lira Filho, $9{ }^{\circ}$ andar, Bloco F, Sala 9122, Maracanã, Rio de Janeiro, RJ, Brazil. 20550-900. julianabrandaoflp@hotmail.com

\begin{abstract}
Introduction: Individuals with schizophrenia tend to have high levels of cortisol and changes in the serotonergic mechanism. However, the effects of aerobic exercises on cortisol and serotonin levels in schizophrenic inpatients are not well established. Objective: To evaluate the effects of an aerobic training program on serotonin and cortisol levels in schizophrenic inpatients. Methods: Thirty schizophrenic subjects were randomly assigned to an exercise group ( $E G ; n=15$; age: $29 \pm 9.08$ years; $B M I: 23.57 \pm 4.33$ $\mathrm{kg} / \mathrm{m}^{2}$ ) or a control group (CG; $\mathrm{n}=15$; age: $33.17 \pm 12.8$ years; $\mathrm{BMl}: 22.89 \pm 5.68 \mathrm{~kg} / \mathrm{m}^{2}$ ). EG performed an aerobic training program in a cycle ergometer (57\% to $67 \%$ of the maximum heart rate) for 30 minutes, five days a week, with a total of twenty sessions. The analysis of cortisol (Chemiluminescence Method) and serotonin (High Performance Liquid Chromatography) was performed before and after testing in both groups. The level of significance was of $p<0.05$. Results: After the exercise sessions, EG showed a significant reduction in cortisol levels $(\Delta=-5.68 \mathrm{mcg} / \mathrm{d} / \%, \mathrm{p}<0.0001)$ and a significant increase in serotonin levels $(\Delta=47.63 \mathrm{ng} / \mathrm{ml}, \mathrm{p}=0.015)$ compared to CG. Conclusion: The aerobic training program was effective in reducing cortisol levels and increasing serotonin levels in schizophrenic inpatients. Level of evidence l; Randomized clinical trial.
\end{abstract}

Keywords: Aerobic exercise; Hormone; Schizophrenia; Cardiorespiratory fitness; Exercise therapy.

\section{RESUMO}

Introdução: Indivíduos com esquizofrenia tendem a apresentar níveis elevados de cortisol e alterações no mecanismo serotoninérgico. Entretanto, os efeitos dos exercícios aeróbicos sobre os níveis de cortisol e serotonina em pacientes esquizofrênicos não estão bem estabelecidos. Objetivos: Avaliar os efeitos de um programa de treinamento aeróbico sobre os níveis de serotonina e cortisol em pacientes esquizofrênicos internados. Métodos: Trinta indivíduos esquizofrênicos foram randomicamente designados para um grupo de exercícios (GE; $n=15$; idade: $29 \pm 9,08$ anos; IMC: $23,57 \pm 4,33 \mathrm{~kg} / \mathrm{m}^{2}$ ) ou para um grupo controle (GC; $n=$ 15; idade: $33,17 \pm 12,8$ anos, IMC: $\left.22,89 \pm 5,68 \mathrm{~kg} / \mathrm{m}^{2}\right)$. O GE realizou um programa de treinamento aeróbico em cicloergômetro (57\% a 67\% da frequência cardíaca máxima) por 30 minutos, cinco dias por semana, totalizando 20 sessões. A análise de cortisol (método quimioluminescente) e serotonina (cromatografia líquida de alta eficiência) foi realizada antes e depois do teste em ambos os grupos. O nível de significância foi de $p<0,05$. Resultados: Depois das sessões de exercício, o GE mostrou redução significativa do nível de cortisol $(\Delta=-5,68 \mathrm{mcg} / \mathrm{dl} \%, p<0,0001)$ e aumento significativo do nível de serotonina $(\Delta=47,63 \mathrm{ng} / \mathrm{ml}, p=0,015)$ em comparação com o GC. Conclusão: O programa de treinamento aeróbico foi efetivo para a redução dos níveis de cortisol e aumento dos níveis de serotonina em pacientes esquizofrênicos. Nível de evidência l; Estudo clínico randomizado.

Descritores: Exercício aeróbico; Hormônios; Esquizofrenia; Aptidão cardiorrespiratória; Terapia por exercício.

\section{RESUMEN}

Introducción: Las personas con esquizofrenia tienden a tener altos niveles de cortisol y cambios en el mecanismo serotoninérgico. Sin embargo, los efectos del ejercicio aeróbico sobre los niveles de cortisol y serotonina en pacientes esquizofrénicos no están bien establecidos. Objetivos: Evaluar los efectos de un programa de entrenamiento aeróbico sobre los niveles de serotonina y cortisol en pacientes esquizofrénicos internados. Métodos: Treinta individuos esquizofrénicos fueron asignados aleatoriamente a un grupo de ejercicio (GE; $n=15$; edad: $29 \pm 9,08$ años; IMC: $23,57 \pm 4,33$ $\mathrm{kg} / \mathrm{m}^{2}$ ) o a un grupo control (GC; $n=15$; edad: $33,17 \pm 12,8$ años, IMC: $22,89 \pm 5,68 \mathrm{~kg} / \mathrm{m}^{2}$ ). GE realizó un programa de entrenamiento aeróbico en cicloergómetro ( $57 \%$ a $67 \%$ de la frecuencia cardíaca máxima) durante 30 minutos, cinco días a la semana, totalizando 20 sesiones. El análisis de cortisol (método quimioluminiscente) y serotonina (cromatografía líquida de alta resolución) se realizó antes y después de la prueba en ambos grupos. El nivel de significación fue $p<0,05$. Resultados: Después de las sesiones de ejercicio, el GE mostró una reducción significativa en el nivel de cortisol $(\Delta=-5,68 \mathrm{mcg} / \mathrm{d} / \%, p<0,0001)$ y un aumento significativo en el nivel de serotonina $(\Delta=47,63 \mathrm{ng} / \mathrm{ml}$, 
Descriptores: Ejercicio aeróbico; Hormonas; Esquizofrenia; Capacidad cardiovascular; Terapia por ejercicio.

\section{INTRODUCTION}

Schizophrenia is a complex mental health condition characterized by severe symptoms that compromise social and occupational functioning. ${ }^{1,2}$ People with schizophrenia may experience delusions and hallucinations, disorganized attitudes and/or speech, apathy and social withdrawal. It affects more than 51 million worldwide occupying the majority of psychiatric beds In Latin America and Brazil. ${ }^{3}$ Frequent hospitalizations and medication side effects affect the physical, cognitive and emotional development of these individuals, impairing the maintenance of the skills necessary to live independently, leading to significant financial and emotional burden for their families. ${ }^{4}$

The antipsychotics use is critical to treat the symptoms, allowing the patient to stay with the family, reducing the number and length of hospitalizations and improving the acceptance within the community. ${ }^{5}$ However, the use of these drugs is related to metabolic changes, ${ }^{6,7}$ such as the endocrine system activation, resulting in an increased release of glucocorticoid hormones. One of these hormones is the cortisol, which is released by the adrenal gland.,8

High levels of plasma cortisol and glucose have also been observed in patients with schizophrenia. ${ }^{1,2}$ The chronic elevation of cortisol can lead to a pseudo-Cushing's syndrome, which is characterized by an increased visceral fat, hyperinsulinemia, insulin resistance, dyslipidemia and hypertension, all markers of the metabolic syndrome. ${ }^{10}$ The serotonergic mechanism is also influenced ${ }^{11}$ since there is a correlation between serotonin level with the hyperprolactinemia in schizophrenic women. ${ }^{12}$

Some studies have investigated the effects of the aerobic exercise on the cortisol level ${ }^{13-15}$ and the serotonin level in the brain of animals. ${ }^{16,17}$ Other studies also indirectly investigated these effects in humans and animals relating to central fatigue ${ }^{18,19}$ and the effect of exercise in healthy people. ${ }^{20}$ However, there are few studies to date, in the scientific literature, about the effects of an aerobic exercise program in the cortisol and serotonin levels of schizophrenic inpatients. ${ }^{1,2}$ Thus, we formulated two hypothesis: the first one supported that exists a direct relationship between the practice of aerobic exercise and the decrease in the cortisol levels. The second hypothesis predicted increases in the serotonin levels after an aerobic exercise program.

Therefore, the aim of this study was to evaluate the effects of an aerobic exercise program on the levels of cortisol and serotonin in schizophrenic inpatients.

\section{MATERIAL AND METHODS}

\section{Sample}

The present research is an experimental study, as it attempts to establish a cause-effect relationship between the variables investigated. ${ }^{21}$

The sample was composed of 30 schizophrenic inpatients (17 women and 13 men). To be included in the study, a subject had to be sedentary for at least six months and do not present any risk factors that could prevent the participation in the study according to the criterion of the Risk Stratification of the American Heart Association. ${ }^{22}$ We excluded individuals with muscular-skeletal anomalies, those who were unable to adapt to the ergometer, and those who had more than $20 \%$ of absences during the intervention.

\section{Measurements and procedures}

For the assessment of the body mass and height, it was used a mechanical scale with a capacity of $150 \mathrm{~kg}$ and $100 \mathrm{~g}$ precision with a stadiometer (Filizola, Brazil). It was used the procedures recommended by the International Society for the Advancement of Kinanthropometry (ISAK). ${ }^{23}$ The body mass index (BMI) was obtained by the ratio of the total body mass (in kilograms) by the square of the height (in meters).

The family responsible for the patients signed a consent form for the participation in research involving human subjects in accordance with the standards of the Declaration of Helsinki and the Resolution 466/12 of the National Health Council. This study was approved by the Research Ethics Committee of Gaspar Vianna Clinical Hospital Foundation (FHCGV), Belém, PA, Brazil, under the number 0372011.

In the day before the hormones collection, the participants of the present study did not ingest the following drinks and foods: coffee, tea, chocolate, soda, avocado, pineapple, plum, banana, eggplant, pickles, kiwi, mango, nuts, tomato, foods flavored with vanilla and any alcoholic beverages. The participants of both groups also fasted for 12 hours before the hormones collection. The blood was collected before 7:30 a.m., in the pre and post-tests, by the same technician skilled nursing. For the blood collection, the subjects remained lying on their beds. For the analysis of the cortisol levels, it was used the enzyme immunoassay Chemiluminescence Method. ${ }^{24}$ Serotonin was analyzed through the High-Performance Liquid Chromatography (HPLC). ${ }^{25}$

\section{Aerobic exercise assessment}

To evaluate the intensity of the aerobic exercise, it was used the percentage of the maximum heart rate (HRmax), using the following formulas for inactive subjects:

HRmax $=206.9$ - age. HR target $=$ between the upper $(0.67 \times \mathrm{HRmax})$ and lower limit $\left(0.57 \times \mathrm{HRmax}^{22}\right.$

\section{Experimental design}

Participants were randomly assigned either to an exercise group (EG: $n=15$ ) or to a control group (CG: $n=15)$. Randomization was performed by simple draw during the receipt of the consent form signed by the family responsible for the patients. The serotonin and cortisol levels were collected pre and post-test for all participants.

\section{Exercise protocol}

Individuals who were randomly assigned to the EG participated in the intervention on a cycle ergometer, five days per week, for 30 min per session, totaling 20 sessions. The aerobic exercise was performed in a moderate intensity, ranging from $57 \%$ to $67 \%$ of the HRmax, measured by a cardiac monitor. A researcher supervised the exercise sessions to ensure the maintenance of the correct training intensity.

\section{Control condition}

After completing the anthropometric, serotonin and cortisol assessment, participants who were randomly assigned to the CG was submitted to daily occupational therapy activities based on reading, painting, and computing three times a week in 30-minute sessions for 4 weeks. Additionally, the CG continued their normal daily activities and agreed not to engage in any regular physical activity for the duration of the study. 


\section{Statistical analysis}

The data were presented in a descriptive way using mean and standard deviation. Normality and variance homogeneity of data were determined using Shapiro-Wilk and Levene tests, respectively. Repeatedmeasures ANOVA was applied to the groups EG and CG (pre and post-test) for intra- and intergroup comparisons, followed by the Scheffé post-hoc test to identify possible differences. The effect size (d) was calculated to analyze the magnitude of the results. It was used for interpretation: $<0.2$ : weak; 0.2 - 0.79: moderate; $\geq 0.8$ : strong. ${ }^{26}$ The significance level was set at $p<0.05$ for all tests. Data were analyzed by the SPSS Statistics 20.0.

\section{RESULTS}

The sample of the present study was composed of patients with paranoid (20\%), catatonic (3.3\%), residual (20\%), simple (3.3\%) and unspecified schizophrenia (53.3\%). In addition to schizophrenia, 13.3\% had hypertension and $13.3 \%$ were smokers. Regarding education level, the majority of the sample (46.7\%) had incomplete fundamentals, 33.3\% had complete fundamentals, $6.7 \%$ had incomplete high school, and 13.3\% had completed high school.

Among the drugs used in the sample were haldol and promethazine (30\%), haldol, promethazine and levomepromazine (13.3\%), haldol, promethazine, levomepromazine and diazepam (26.7\%), haldol, promethazine and diazepam (3.3\%), haldol, promethazine and chlorpromazine (10\%), risperidone and promethazine (10\%), and risperidone, promethazine and diazepam (6.7\%).

Table 1 shows the characteristics and hormone levels of both groups of the present study. It was observed that there was normal data distribution for all studied variables in both groups.

Figure 1 presents the results on the cortisol levels intra- and intergroups in the pre- and post-test moments. It was observed that the EG obtained a significant reduction in the cortisol levels from the pre- to the post-test $(\Delta=-5.68 \mathrm{mcg} / \mathrm{dl} ; \mathrm{p}<0.0001$, confidence interval $(\mathrm{Cl})=$ $2.11,9.24)$. This did not occur with the CG. In the inter-group analysis, the EG had significantly lower levels of cortisol, when compared to CG $(\Delta=-6.50 \mathrm{mcg} / \mathrm{dl} ; \mathrm{p}<0.0001, \mathrm{Cl}=-10.48,-2.51)$ in the post-test. These results are confirmed by the effect size found $(d=2.61>0.8)$, which is considered to be strong.

Figure 2 shows the intra- and inter-group comparisons of serotonin levels. The EG had a significant increase from the pre- to the post-test $(\Delta=39.57 \mathrm{ng} / \mathrm{ml} ; \mathrm{p}=0.027, \mathrm{Cl}=-75.87,-3.28)$. The same did not occur in the CG. The inter-group analysis results showed that the EG had higher serotonin levels when compared to $C G(\Delta=47.63 \mathrm{ng} / \mathrm{ml} ; \mathrm{p}=0.015$, $\mathrm{Cl}=7.05,88.20)$ in the post-test. These results are confirmed by the effect size found $(d=1.01>0.80)$, considered strong.

Table 1. Characteristics and hormone levels of the sample.

\begin{tabular}{c|c|c|c|c}
\hline Groups & Variables & Mean & SD & p-value (SW) \\
\hline \multirow{4}{*}{ EG } & Age (years) & 29.00 & 9.08 & 0.055 \\
\cline { 2 - 5 } & Body mass $(\mathrm{kg})$ & 61.09 & 12.87 & 0.431 \\
\cline { 2 - 5 } & Height $(\mathrm{m})$ & 1.61 & 0.08 & 0.625 \\
\cline { 2 - 5 } & BMl $\left(\mathrm{kg} / \mathrm{m}^{2}\right)$ & 23.57 & 4.33 & 0.989 \\
\cline { 2 - 5 } & Serotonin $(\mathrm{ng} / \mathrm{ml})$ & 122.06 & 38.12 & 0.829 \\
\cline { 2 - 5 } & Cortisol $(\mathrm{mcg} / \mathrm{dl})$ & 12.07 & 5.38 & 0.671 \\
\hline \multirow{4}{*}{ CG } & Age (years) & 33.17 & 12.80 & 0.589 \\
\cline { 2 - 5 } & Body mass $(\mathrm{kg})$ & 58.90 & 15.36 & 0.823 \\
\cline { 2 - 5 } & Height $(\mathrm{m})$ & 1.60 & 0.12 & 0.171 \\
\cline { 2 - 5 } & BMl $\left(\mathrm{kg} / \mathrm{m}^{2}\right)$ & 22.89 & 5.68 & 0.052 \\
\cline { 2 - 5 } & Serotonin $(\mathrm{ng} / \mathrm{ml})$ & 117.61 & 41.43 & 0.627 \\
\cline { 2 - 5 } & Cortisol $(\mathrm{mcg} / \mathrm{dl})$ & 13.13 & 2.02 & 0.109 \\
\hline
\end{tabular}

SD: standard deviation; BMI: body mass index; EG: exercise group; CG: control group; SW: Shapiro-Wilk test.

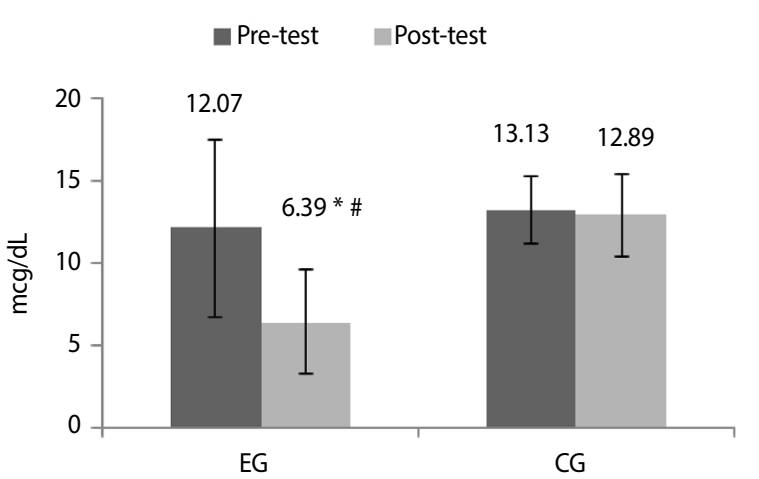

EG: exercise group; CG: control group; * $p<0.05$, EG-pre vs. EG-post; \# p<0.05, EG-post vs. CG-post.

Figure 1. Analysis of the cortisol levels in the EG and CG.

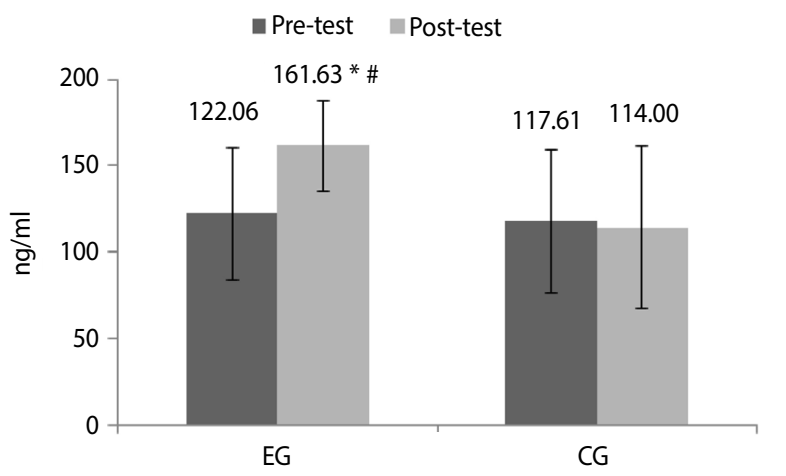

EG: exercise group; CG: control group; * $\mathrm{p}<0.05$, EG-pre vs. EG-post; \# p<0.05, EG-post vs. CG-post.

Figure 2. Analysis of the serotonin levels in EG and CG.

\section{DISCUSSION}

The results of the present study confirmed the initial hypotheses formulated, as they presented a significant reduction in the levels of cortisol in the EG in relation to the $C G$, and a significant increase in the levels of serotonin in the EG when compared to the CG.

Cortisol is a neuroendocrine indicator of the individual's response to stress situations, whose production and control are due to the action of the hypothalamic-pituitary-adrenal (HPA) axis. ${ }^{27}$ Exposure to continuous stress results in chronic elevations in cortisol production, which inhibits the participation of the negative feedback system responsible for the decrease in HPA activity. ${ }^{28}$ This inhibition may activate excess neurotransmission of dopamine and lead to the exacerbation of the negative symptoms of schizophrenia, both psychotic (memory deficit, poor cognitive performance, mental confusion, state anxiety), as well as physical (motor uncontrollability, low effort tolerance), making the quality of life deficient. ${ }^{29}$ Comorbidities such as metabolic syndrome, hypertension, and type 2 diabetes may appear in more severe cases. ${ }^{30}$ Due to this situation, aerobic exercises have been proposed as an adjuvant therapy for the usual drug treatments. ${ }^{31}$

In a longitudinal investigation carried out during 3 months with 149 Chinese patients with chronic schizophrenia and age between 18 and 65 years, Ho et al.' reported that individuals who walked recreationally for up to 30 minutes per day reduced salivary cortisol diurnal production significantly more than those not involved in physical exercise. These findings were also found in the present study. However, Ho et al. ${ }^{2}$ observed, in another 6-month longitudinal study with 153 chronic schizophrenics, that the groups of subjects undergoing an exclusive Tai-chi program $(n=51)$ and aerobic exercise $(n=51)$ showed significant increases in daily cortisol levels when compared to the CG $(n=51)$. 
This result, in turn, contradicts the findings of the present study. Nevertheless, patients in both groups (Tai-chi and aerobic exercise) exhibited increases in attention, memory and motor skills. Both studies indicate that the endocrine responses of the patients to the motor stimuli proposed in the therapeutic exercise program were specific and differentiated. The pathophysiological state, metabolic efficiency and the ability of each subject may have influenced these effects. ${ }^{2}$

Pajonk et al. ${ }^{32}$ found this trend on cortical adaptations in their experimental study with 8 male patients diagnosed with chronic schizophrenia. These subjects were exposed to aerobic activity of 30 minutes on a cycle ergometer for 12 weeks, frequency of three times per week and effort intensity comprised between 1.5 and $2.0 \mathrm{mmol} / \mathrm{L}$ of blood lactate. The CG consisted of 8 schizophrenic individuals practicing table football three times a week for 30 minutes. There was a 12\% increase in hippocampal volume in the aerobic exercise group compared to a decrease of $1 \%$ observed in schizophrenic patients who played table football. Changes in hippocampal volume had a positive correlation with cardiorespiratory fitness, measured by changes in maximum oxygen consumption ( $r=0.71 ; p=0.03)$.

Scheewe et al. ${ }^{33}$ investigated 18 chronic schizophrenics who underwent a mixed protocol of aerobic exercises (using cycle ergometers, rowing machine, cross-trainer, and treadmill) and resistance training during 6 months, twice a week, with 40-minute training sessions and 75\% maximum HR intensity. The CG consisted of 14 schizophrenic subjects who underwent occupational therapy twice a week for 6 months. At the end of the intervention, there were increases in cardiorespiratory fitness and in the thickness of areas of the left cerebral cortex of the group submitted to the mixed protocol of exercises when compared to the CG.

The previous information reinforces the hypothesis that aerobic exercise can provide beneficial effects to the endocrine, cardiorespiratory and neurocognitive functions of schizophrenics. In this sense, Vancampfort et al. ${ }^{34}$ states that the adaptations provided by short, medium and long term training for subjects with mental disorders such as schizophrenia are conditioned by particular clinical settings, body mass indexes, characteristics of the drugs consumed, initial states of motor fitness and type, volume and intensity of body movement performed.

The other hormone analyzed in the present study was serotonin (5-HT), which is a neurotransmitter that acts doubly as a conduit inhibitor and a general modulator of psychic activity. Variations in the brain concentrations of serotonin refer to oscillations in anxiety, aggression, depression, prostration and fatigue. ${ }^{35}$

The results in the present study showed elevated serotonin levels in the EG. These findings were similar to those obtained by Valim et al., ${ }^{36}$ who analyzed 22 women with fibromyalgia and with symptoms of depression. Participants were randomized into one group of aerobic walking exercise and another group of stretching exercise, both performed three times a week, for 20 weeks. Pre- and post-intervention group analyzes showed that serum 5-HT levels increased significantly in the aerobic group over the 20-week therapy period ( $p=0.03$ ). The stretching group showed no change ( $p=0.491)$.

Other investigations have reported an inverse relationship between serotonin concentrations and aerobic exercise. Wipfli et al..$^{20}$ analyzed the impacts of aerobic exercise on symptoms of depression and anxiety through a 7-week intervention program in 72 untrained subjects randomly distributed in two groups, one of aerobic exercises and the other of yoga (control group). The aerobic exercise group $(n=35)$ underwent 30 minutes of stationary cycling three times a week at 70\% of maximal heart rate, while the control group performed series of static yoga positions for 15 to 30 seconds with 10 to 20 seconds of rest in sessions with the same duration and weekly frequency. At the end of the intervention, the aerobic exercise group showed a greater reduction in serotonin concentrations compared to the yoga control group ( $p<0.05)$.

Similarly, Oliveira et al. ${ }^{37}$ randomly separated 48 elderly women, aged between 50 and 72 years, who presented mild depression symptoms, into an experimental group $(n=28)$ and a control group $(n=20)$. During 8 weeks, the EG performed resistance and aerobic exercises three times a week, in 40-minute sessions and training intensity ranging from 65\% to $75 \%$ of maximal heart rate. The CG performed occupational therapy (painting, gardening and drawing). At the end of the program, laboratory analyzes showed that the EG had a significant decrease in serum serotonergic levels $(p=0.01)$.

The previously listed studies indicate that serotonin produced as a function of performing aerobic activities can both overcome and retreat in relation to pre-exercise levels. This association with the measurement of aerobic fitness is important for schizophrenic patients, as well as stratification of changes in cortisol and serotonin levels based on ingested drug dosages. However, the present study did not controlled this variable, which can be considered a limitation.

Thus, a limitation of the present study was that it did not correlate the variations in serotonin and cortisol serum levels of CG and EG with the amounts of drugs ingested before and during the intervention program. These factors probably can better explain the metabolic responses to exercise and the quality of motor performance.

\section{CONCLUSION}

The present study characterizes its original aspect because it is performed on a sample of hospitalized schizophrenic subjects, needing more attention on endocrine aspects, due to a high incidence of metabolic syndrome in this population. This study concludes that the practice of an aerobic exercise program reduces the cortisol level and increases serotonin level in schizophrenic inpatients, probably helping to decrease the side effects of drugs. The aerobic program was effective in reducing the level of cortisol and increasing the levels of serotonin in schizophrenic inpatients.

All authors declare no potential conflict of interest related to this article

AUTHORS' CONTRIBUTIONS: Each author made significant individual contributions to this manuscript. LGSC: writing, intellectual concept and preparation of the entire research project; DRNG: writing and analysis of the data; JBPC: writing, analysis of the data, interpretation of the data for the work, revision, and formatting; KRSGO: writing, intellectual concept and preparation of the entire research project; RGSV: writing, statistical analysis, analysis of the data and revision. All the authors revised and approved the final version of the manuscript.

\section{REFERENCES}

1. Ho RT, Fong TC, Wan AH, Au-Yeung FS, Chen EY, Spiegel D. Associations between diurnal cortisol patterns and lifestyle factors, psychotic symptoms, and neurological deficits: a longitudinal study on patients with chronic schizophrenia. J Psychiatr Res. 2016a;81:16-22.

2. Ho RT, Fong TC, Wan AH, Au-Yeung FS, Wong CP, Ng WY, et al. A randomized controlled trial on the psychophysiological effects of physical exercise and Tai-chi in patients with chronic schizophrenia. Schizophr Res. 2016b;171(1-3):42-9.

3. World Health Organization - WHO. Schizophrenia: key facts. [Access 202 April 9]. Available in: http:// www.who.int/news-room/fact-sheets/detail/schizophrenia
4. McCullumsmith RE, Clinton SM, Meador-Woodruff JH. Schizophrenia as a disorder of neuroplasticity. Int Rev Neurobiol. 2004; 59:19-45.

5. Gama CS, Souza CM, Lobato MI, Abreu PS. Clozapine use report in 56 patients seen by Clerkship of Health and Environment of the State of Rio Grande do Sul's Program of Attention to the Refractory Schizophrenia. Rev Psiquiatr Rio Gd Sul. 2004;26(1):21-8.

6. Gardner DM, Baldessarini RJ, Waraich P. Modern antipsychotic drugs: a critical overview. CMAJ. 2005;172(13):1703-11.

7. Leitão-Azevedo CL, Abreu MG, Guimarães LR, Moreno D, Lobato MI, Gama CS, et al. Sobrepeso e obesidade 
em pacientes esquizofrênicos em uso de clozapina comparado com o uso de outros antipsicóticos. Rev Psiquiatr Rio Gd Sul. 2006;28(2):12-8.

8. Canali ES, Kruel LF. Respostas hormonais ao exercício. Rev Paul Educ Fís. 2001;15(2):141-53

9. Duclos $M$, Gouarné C, Bonnemaison D. Acute and chronic effects of exercise on tissue sensitivity to glucocorticoids. J Appl Physiol (1985). 2003;94(3):869-75.

10. Parker KJ, Schatzberg AF, Lyons DM. Neuroendocrine aspects of hypercortisolism in major depression. Horm Behav. 2003;43(1):60-6.

11. Miller D, Tandon R. The biology and pathophysiology of negative symptoms. In: Keefe, RSE, Mc Evoy PJ, editors. Negative symptom and cognitive deficit treatment response in schizophrenia. Washington: American Psychiatric Press; 2001. p.163-86.

12. Compton MT, Miller AH. Antipsychotic-induced hyperprolactinemia and sexual dysfunction. Psychopharmacol Bull. 2002;36(1):143-64.

13. Grandys M, Majerczak J, Duda K, Zapart-Bukowska J, Sztefko K, Zoladz JA. The effect of endurance training on muscle strength in young, healthy men in relation to hormonal status. J Physiol Pharmacol. 2008:59(Suppl 7):89-103.

14. Vale RG, Oliveira RD, Pernambuco CS, Meneses YP, Novaes JS, Andrade AF. Effects of muscle strength and aerobic training on basal serum levels of IGF-1 and cortisol in elderly women. Arch Gerontol Geriat. 2009:49(3):343-7.

15. Moraes H, Deslandes A, Maciel-Pinheiro PT, Corrêa H, Laks J. Cortisol, DHEA, and depression in the elderly: the influence of physical capacity. Arq Neuropsiquiatr. 2016;74(6):456-61.

16. Jacobs BL, Fornal CA. 5-HT and motor control: a hypothesis. Trends Neurosci. 1993;16:346-52

17. Chaouloff F. Effects of acute physical exercise on central serotonergic systems. Med Sci Sports Exerc. 1997;29(1):58-62

18. Bailey SP, Davis JM, Ahlborn EN. Serotonergic agonists and antagonists affect endurance performance in the rat. Int J Sports Med. 1993;14(6):330-3.

19. Kubitz KA, Landers DM, Petruzzello SJ, Han M. The effects of acute and chronic exercise on sleep. A meta-analytic review. Sports Med. 1996;21(4):277-91.

20. Wipfli B, Landers D, Nagoshi C, Ringenbach S. An examination of serotonin and psychological variables in the relationship between exercise and mental health. Scand J Med Sci Sports. 2011;21:474-81.

21. Thomas JR, Nelson JK, Silverman SJ. Métodos de pesquisa em atividade física. 6. ed. Porto Alegre: Artmed; 2012.

22. American College of Sports Medicine. ACSM's Guidelines for exercise testing and prescription. 8th ed. Philadelphia: Lippincott Williams \& Wilkins; 2010
23. Marfell-Jones M, Olds T, Stewart AC. International standards for anthropometric assessment. Potchefstroom, South Africa: ISAK; 2006

24. Kohe F, Pazzagli M, Kim JB, Lindner HR. An immunoassay for plasma cortisol based on chemiluminescence Steroids. 1980;36(4):421-37.

25. Lacassie E, Gaulier JM, Marquet P, Rabatel JF, Lachâtre G. Methods for the determination of seven selective serotonin reuptake inhibitors and three active metabolites in human serum using high-performance liquid chromatography and gas chromatography. J Chromatogr B Biomed Sci Appl. 2000;742(2):229-38.

26. Cohen J. Statistical power analysis for the behavioral sciences. 2nd ed. Hillsdale, NJ: Lawrence Erbaum; 1988

27. Hempel RJ, Tulen JH, van Beveren NJ, Roder $\mathrm{CH}$, Jong FH, Hengeveld MW. Diurnal cortisol patterns of young male patients with schizophrenia. Psychiatry Clin Neurosci. 2010;64(5):548-54.

28. Dallman MF, Akana S, Strack AM, Scribner KS, Pecoraro N, La Fleur SE, et al. Chronic stress-induced effects of corticosterone on brain: direct and indirect. Ann NY Acad Sci. 2004;1018(1):141-50.

29. Fogarty M, Happell B. Exploring the benefits of an exercise program for people with schizophrenia: a qualitative study. Issues Mental Health Nurs. 2005;26(3):341-51.

30. Manzanares N, Monseny R, Ortega L, Montalvo I, Franch J, Gutiérrez-Zotes A, et al. Unhealthy lifestyle in early psychoses: the role of life stress and the hypothalamic-pituitary-adrenal axis. Psychoneuroendocrinology. 2014;39:1-10.

31. Heijnen S, Hommel B, Kibele A, Colzato LS. Neuromodulation of aerobic exercise: a review. Front Psychol. 2016;6:1890

32. Pajonk FG, Wobrock T, Gruber O, Scherk H, Berner D, Kaizl I, et al. Hippocampal plasticity in response to exercise in schizophrenia. Arch Gen Psychiatry. 2010;67(2):133-43. http://dx.doi.org/10.1001/ archgenpsychiatry.2009.193

33. Scheewe TW, van Haren NE, Sarkisyan G, Schnack HG, Brouwer RM, Glint M, et al. Exercise therapy, cardiorespiratory fitness and their effect on brain volumes: a randomised controlled trial in patients with schizophrenia and healthy controls. Eur Neuropsychopharmacol. 2013;23(7):675-85.

34. Vancampfort D, Probst M, De Hert M, Soundy A, Stubbs B, Stroobants M, et al. A. Neurobiologica effects of physical exercise in schizophrenia: a systematic review. Disabil Rehabil. 2014;36(21):1749-54.

35. Feijó FM, Bertoluci MC, Reis C. Serotonin and hypothalamic control of hunger: a review. Rev Assoc Med Bras (1992). 2011;57(1):74-7.

36. Valim V, Natour J, Xiao Y, Pereira AF, Lopes BB, Pollak DF, et al. Effects of physical exercise on serum levels of serotonin and its metabolite in fibromyalgia: a randomized pilot study. Rev Bras Reumatol. 2013;53(6):538-41.

37. Oliveira RJ, Lopes KM, Córdova C, Bottaro M. Aerobic training and the changes on the serum levels of serotonin and in the symptoms of depression in elderly women. Biol Sport. 2007;24(3):255-64. 